\title{
Isolation and characterization of proteases enzyme from locally isolated Bacillus sp.
}

\author{
Md. Ekhlas Uddin ${ }^{1}$, Pulak Maitra ${ }^{1, ~ *, ~ H o s s a i n ~ M d . ~ F a r u q u e e ~}{ }^{1,2}$, Md. Firoz Alam \\ ${ }^{1}$ Dept. Of Biotechnology \& Genetic Engineering, Islamic University, Kushtia, Bangladesh \\ ${ }^{2}$ Vaccine research Laboratory, Gono University, Savar, Dhaka
}

\section{Email address:}

dipubtge03@gmail.com (Md. E. Uddin),pulakbge22@gmail.com (P. Maitra), faruquee@btge.iu.ac.bd (H. Md. Faruquee), firozbt21@gmail.com (Md. Firoz Alam)

\section{To cite this article:}

Md. Ekhlas Uddin, Pulak Maitra, Hossain Md. Faruquee, Md. Firoz Alam. Isolation and Characterization of Proteases Enzyme from Locally Isolated Bacillus sp.. American Journal of Life Sciences. Vol. 2, No. 6, 2014, pp. 338-344. doi: 10.11648/j.ajls.20140206.12

\begin{abstract}
A bacterium was isolated from the natural source. Gram staining \& spore staining showed that the organism is gram positive and forms spore during adverse condition in the growth medium. After various tests it was suggested and the features agreed with the description of Bacillus sp in Bergey's Manual of Systematic Bacteriology [24]. It was also identified as Bacillus sp with $99.9 \%$ identity by API 50 CHB. In growth curve determination showed that the growth of the organism is increased with the increase of incubation period and the growth reached maximum at around 24 hours of incubation and the protease activity was the maximum of the 26 hours culture. This microbe has grown at high temperature and pressure. Its optimum $\mathrm{pH}$ and temperature were 8.5 and $60^{\circ} \mathrm{C}$. It secretes an extracellular protease in the growth medium. The enzyme hydrolyses a number of proteins including azocasein which suggests that that it is an extracellular protease. The enzyme seems to be alkaline protease which is capable of De-Hairing from skin and hides. A number of companies such as NOVO chemicals started to produce NOVOzymes for tannery industries. The potential for use of microbial enzymes in leather processing lies mainly in areas in which pollution-causing chemicals are being used.
\end{abstract}

Keywords: Identification, Characterization of Protease, Bacillus sp., Isolation, Alkaline Protease

\section{Introduction}

Leather is the third largest economic community of Bangladesh. Its industrial production is very beneficial to the country in terms of employment generation as well as foreign exchange earner. Though leather industrial has been set up sporadically house and there in the country it has not yet developed scientifically in an organized way. Recently government of People's Republic of Bangladesh has taken initiative to develop the industry from outside the city and modernize it. Enzymatic De-Hairing in tanneries has been envisaged as an alternative to sulfides [3, 5, 9, 26, 27 ]. Over the last few decades leather industry is based on large scale chemicals treatment which created worldwide environmental hazards. The chemicals which were used in pre-tanning stage were soda-lime, salts, solvent flashy and biological waste from leather itself. In fact, the raw hides had to undergo a series of chemical treatment before it turned into flattering leather. The chemicals used in this process were mostly toxic. Thus due to these pre-tanning operations, the leather processing industry is one of the worst offenders of the environment. Enzymatic De-Hairing is suggested as an environment friendly alternative to the conventional chemical process [18]. The use of proteolytic enzymes as an alternative to De-Hairing skins has been investigated [20]. In the back drop of this scenario enzymes started replacing poisonous chemicals from tannery industries. A number of industries such as NOVO chemicals started producing NOVOzymes for the tannery industries.

With the advent of enzymes leather processing in various countries has become environment friendly. Many countries including India has started tannery industries based on enzymatic process. This industry needs a lot of enzymes for soaking, digressing and De-Hairing. Besides enzyme are used for depollution, effluents treatment and by product utilization. In this context proteases could play an important part in biotechnological applications like enzymatic improvement of feather meal and production of amino acids or peptides from high-molecular weight substrates or in the leather industry [6, 12]. These enzymes could be applied for waste water 
treatment, textile, medicine, cosmetic leather and poultry processing industry as well as in the leather industry [17].

\section{Materials and Methods}

\subsection{Isolation and Identification of Bacteria from Local Soil Sample}

The soil sample was collected from the poultry wastes in local area, after serial dilution, culture were given in LB broth media from the sample for $16 \mathrm{~h}$ at $37^{\circ} \mathrm{C}$. At the next day single colony was found. Among them few colonies were identified on the basis of different colony morphology. Each colony was inoculated into screw capped test tubes containing autoclaved feather with liquid broth media and incubated overnight at $37^{\circ} \mathrm{C}$ with shaking at $160 \mathrm{rpm}$. Gram's staining; morphological studies, physiological and biochemical characteristics of the isolate were investigated according to Bergey's Manuals [24]. A rapid bacterial identification test kit for Bacillus, API $50 \mathrm{CHB}$, was used to identify species of bacteria. Probabilistic identification of bacterial strains (PIB) were conducted by using a bioinformatics tool, were used. In this tool, different morphological and biochemical tests were given as input data and the program utilize a pre-existing database and compare with the input data. This bioinformatics toll gives a index (ID) value as output. This index value represents the probability of the strain.

\subsection{Azocasein Test}

Azocasein test, described by Kreger and Lockwood (1981) was done to measure the proteolytic activity of the feather degrading Bacteria. Here azocasein was used as substrate. Optical density was measured at $440 \mathrm{~nm}$.

\subsection{Biochemical \& Microbiological Tests for bacteria Characterization}

To identify the bacteria biochemical properties, of different tests were performed. For correct interpretation of the results in every test Escherichia coli was taken as control. Carbohydrate tests were performed using Glucose, Lactose, Ribose, Sucrose, Mannitol, Adonitol, Arabinose, Sorbitol and Maltose.

Others biochemical tests were performed such as Hydrogen sulfide test, Motility Test, Indole Production Test, Citrate Utilization Test, Nitrate Reduction Test, Oxidase test (young culture), Catalase Test, Urease test, Indole (SIM) test, Methyl Red (MR) Voges- Proskauer (VP) Test, Starch Hydrolysis Test and Gelatin Liquefaction Test. Some Microbiological tests that were performed are the Gram staining for the Bacteria, Spore staining, colony morphology and growth curve determination.

\subsection{Determination of Temperature effect on Protease Activity}

For the determination of the effect of temperature, the reaction medium was incubated at $37^{\circ}, 40^{\circ}, 50^{\circ}, 60^{\circ}, 65^{\circ} \mathrm{C}$ temperatures and the protease activity was determined. For this purpose the enzyme preparation was added to a mixture of $1 \mathrm{mg} 1 \%$ azocasein solution, $0.1 \mathrm{ml}$ of $0.06 \mathrm{M} \mathrm{CaCl} 2$ and buffer (0.2 M Tris-HCI buffer, $\mathrm{pH} 8.0)$.

\subsection{Determination of pH effect on Protease Activity}

For determining the effect of $\mathrm{pH}$ on protease activity different buffer systems with different $\mathrm{pH}$ were used. Azocasein was dissolved in different buffer solution and the enzyme assay was carried out within a $\mathrm{pH}$ range of 4.0 to 10.5 by azocasein assay method. All of them were used at $0.05 \mathrm{M}$ concentration.

Table 1. Different buffer used and their $p H$ ranges

\begin{tabular}{ll}
\hline Buffer & pH range \\
\hline Acetate buffer & $4.0-5.6$ \\
Sodium phosphate buffer & $5.6-8.0$ \\
Tris $\mathrm{HCl}$ buffer & $7.5-8.9$ \\
Glycine-NaOH buffer & $8.6-10.5$ \\
\hline
\end{tabular}

\subsection{Determination of effect of other effectors on Protease Activity}

The activity of the isolated protease was tested in the presence of various known protease effectors (all obtained from Sigma Chemical Co.), EDTA, 2-mercaptoethanol, potassium di-chromate, sodium thiosulfate. The azocasein assay was used with the addition of these effectors solution to achieve a final desired effectors concentration of $5 \mathrm{mM}$. Control was taken where azocasein assay without these effectors was carried out.

\subsection{Determination of salts effect on Protease Activity}

The protease activity was measured with adding different salts like $\mathrm{ZnSO}_{4}, \mathrm{MgSO}_{4}, \mathrm{CuSO}_{4}, \mathrm{NaCl}, \mathrm{KCl}$ at different concentration and then azocasein assay was performed.

\subsection{Determination of Temperature effect on Bacterial Growth and Protease Activity}

The bacterial culture was grown in nutrient broth at various temperatures $\left(25^{\circ} \mathrm{C}, 30^{\circ} \mathrm{C}, 35^{\circ} \mathrm{C}, 40^{\circ} \mathrm{C}, 50^{\circ} \mathrm{C}, 60^{\circ} \mathrm{C}\right)$ and was incubated for 48 hours to measure its growth profile. For the determination of the effect of temperature, the culture medium was incubated at temperature ranging from $25-60^{\circ} \mathrm{C}$ and the protease activity was determined at $37^{\circ} \mathrm{C}$ using the usual methods.

\subsection{Direct dehairing activity of the enzyme}

For De-Hairing studies, the organism was grown in nutrient broth at $37^{\circ} \mathrm{C}$ for around 20 hours. Then it was centrifuged at $4000 \mathrm{rpm}$ for 8 minutes. The cell free supernatant was added on detergent washed goat skin to observed enzymatic De-Hairing capability of the organism. Sodium azide was used at $1 \%$ so that no organism can grow. Nutrient broth was used as control. 


\section{Result and Observation}

\subsection{Bacteria Isolation and Characterization}

The main object of this work was to isolate and characterize the thermophilic enzyme which could specifically be used for De-Hairing the hides and skins of cattle in the tannery industries. In this connection three ways were planned. One was to isolate thermophilic organism from different natural sources. The others is to characterize \& identification of the isolated organism. The growth phenotype and some of the biochemical characteristics of the organism was determined.
This organism was characterized and identified as a member of gram positive Bacillus family by several test. The features agreed with the description of Bacillus subtilis in Bergey's Manual of Systematic Bacteriology [24]. It was also identified as B. subtilis with $99.9 \%$ identity by API 50 CHB and was also characterized and identified by using a bioinformatics tool PIB (Probabilistic Identification of Bacteria) that suggests the organism was $B$. subtilis $(I D=0.9760)$. So this bacteria is named here as a Bacillus subtilis. The results are presented in table-2

Table 2. Different morphological and biochemical test for the identification of B. subtilis

\begin{tabular}{|c|c|c|}
\hline Test performed & Observations & Results \\
\hline \multicolumn{3}{|l|}{ Streak plate isolation: } \\
\hline $\mathrm{NA}$ at $37^{\circ} \mathrm{C}$ & milky colonies & Positive \\
\hline Gram stain & Small violate colonies singly & Gram positive rods \\
\hline Spore stain & green color appeared & spore forms \\
\hline \multicolumn{3}{|l|}{ Cultural characteristics: } \\
\hline Nutrient Agar plates & growth on NA plates & small, non-pigmented, circular \\
\hline Nutrient Broth & growth on NB & uniform fine turbidity \\
\hline Nutrient agar slants & Growth on NA slant & moderate, non pigmented \\
\hline Catalase test & bubbles formed & Positive for catalase production \\
\hline Oxidase test & Black color formed & positive for oxidase production \\
\hline \multicolumn{3}{|l|}{ Acid \& gas production: } \\
\hline Glucose & Yellow & positive for acid and negative for gas \\
\hline Sucrose & Yellow & positive for acid only \\
\hline Mannitol & Red & Negative for acid and gas \\
\hline Adonitol & Red & Negative for acid and gas \\
\hline Arabinose & Yellow & positive for acid only \\
\hline Sorbitol & Red & Negative for acid and gas \\
\hline Maltose & Red & Negative for acid and gas \\
\hline \multicolumn{3}{|l|}{ IMViC test: } \\
\hline Indole (SIM) test & bright red ring, growth away & Positive for indole and motility \\
\hline $\mathrm{H}_{2} \mathrm{~S}$ test & from stab, black color & Positive for $\mathrm{H} 2 \mathrm{~S}$ production \\
\hline Methyl red test & deep red ring formed & positive for mixed acid production \\
\hline Voges-Proskauer test & weak red ring formed & positive for acetoin production \\
\hline Citrate test & change in color & positive for citrate utilization \\
\hline Urease test & no bright pink color & negative for urea catabolism \\
\hline Nitrate test & no color change after zinc dust addition & positive for nitrate reduction \\
\hline Gelatin test & remain liquefied at $4^{\circ}$ & positive for gelatinase production \\
\hline Starch test & bright zone & positive for starch hydrolysis \\
\hline
\end{tabular}

\subsection{Azocasein Test}

The proteolytic activity is found as 21.13 units for the sample. One unit of proteolytic activity is defined as the amount of enzyme that produces an increase in the absorbance of 0.01 at $440 \mathrm{~nm}$.

\subsection{Temperature effect on Enzyme Activity}

The activity of the enzyme was measured over a range of temperature $\left(0^{\circ} \mathrm{C}, 4^{\circ} \mathrm{C}, 20^{\circ} \mathrm{C}, 30^{\circ} \mathrm{C}, 37^{\circ} \mathrm{C}, 40^{\circ} \mathrm{C}, 50^{\circ} \mathrm{C}, 60^{\circ} \mathrm{C}\right.$, $65^{\circ} \mathrm{C}, 80^{\circ} \mathrm{C}$ ) and the result is presented in Table- 3 and Figure- 1

Table3. Protease activity at different temperature (by Kreger and Lockwood method).

\begin{tabular}{ll}
\hline Temperature & Absorbance at 440nm \\
\hline $0^{\circ} \mathrm{C}$ & 0.009 \\
$4{ }^{\circ} \mathrm{C}$ & 0.019 \\
$20^{\circ} \mathrm{C}$ & 0.121 \\
$30^{\circ} \mathrm{C}$ & 0.181 \\
$37^{\circ} \mathrm{C}$ & 0.183 \\
$40^{\circ} \mathrm{C}$ & 0.191 \\
$50^{\circ} \mathrm{C}$ & 0.205 \\
$60^{\circ} \mathrm{C}$ & 0.250 \\
$65^{\circ} \mathrm{C}$ & 0.105 \\
$80^{\circ} \mathrm{C}$ & 0.019 \\
\hline
\end{tabular}


The enzyme activity is increased with the increase of temperature. The experiment was reported 2 times and the result is reproducible. There was a significant increase in enzyme activity between $20^{\circ} \mathrm{C}$ to $55^{\circ} \mathrm{C}$. The enzyme seems to be active at $60^{\circ} \mathrm{C}$ and its activity declines as the temperature increase beyond $60^{\circ} \mathrm{c}$.It should be demonstrated that the enzyme has its activity after a second round of temperature.

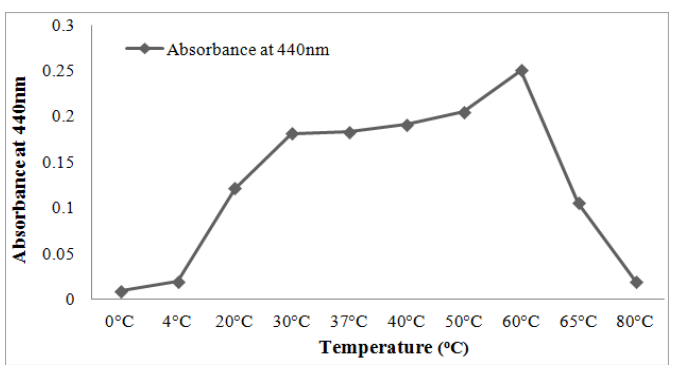

Fig 1. Graphical presentation of protease activities at different temperature

Fig-1 shows that the protease was active over a temperature range of $4^{\circ} \mathrm{C} \sim 80^{\circ} \mathrm{C}$, with an optimum at $60^{\circ} \mathrm{C}$.

\section{4. pH effect on Protease Activity}

Reaction media $\mathrm{pH}$ can affect the protease activity. To evaluate this information the enzyme activity over a $\mathrm{pH}$ range between 4 and 11 was assayed. The maximum enzyme activity was observed at $\mathrm{pH} 8.5$. The activity declines at $\mathrm{pH} 8.0$ or above 8.5. Therefore $\mathrm{pH} 8.5$ might be the optimum $\mathrm{pH}$ for enzyme activity. Additionally, its optimum $\mathrm{pH}$ was similar to that of previous reports [22]. Most proteases are active in neutral to alkali conditions, from $\mathrm{pH} 7.0$ to $\mathrm{pH}$ 9.5. For example, the activity optimum of protease from Mycobacterium kr10 is $\mathrm{pH} 7.0$ [19], B. pumilus FH9 of pH 8.0 [7], Fervidobacterium islandicum AW-1 of pH 9.0 [18].

Table 4. Effect of pH on Protease Activity

\begin{tabular}{ll}
\hline $\mathbf{p H}$ & Activity of Enzyme(unit) \\
\hline 4.0 & 28 \\
5.0 & 36.5 \\
6.0 & 48 \\
7.0 & 63 \\
8.0 & 68 \\
8.5 & 70 \\
9.0 & 66 \\
10 & 60 \\
11 & 48 \\
\hline
\end{tabular}

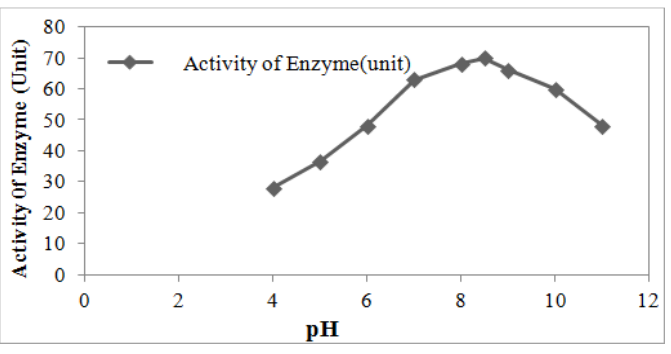

Fig 2. Graphical presentation of effect of $\mathrm{pH}$ on protease activity

In fig- 2 showed that the enzyme activity increases with the increase of $\mathrm{pH}$ of the media. The results showed that the optimum $\mathrm{pH}$ of the protease enzyme was 8.5. Studies on growth temperature and $\mathrm{pH}$ suggest that the organism might be alkaline and thermophilic Bacillus.

\subsection{Effect of Salts and other Effectors on the Protease Activity}

The effect of different salts $\left(\mathrm{MgSO}_{4}, \mathrm{ZnSO}_{4}, \mathrm{CuSO}_{4}, \mathrm{NaCl}\right.$, $\mathrm{KCl}$ ) and other effectors (EDTA, 2-mercaptoethanol, sodium thiosulfate) at different concentration was measured. $\mathrm{MgSO}_{4}$ increased the activity and $\beta$-Mercaptoethanol decreased the activity of the enzyme. $\mathrm{NaCl}$ didn't change the protease activity. Others had little deactivating effect.

Table 5. Effects of salts and other chemicals on the activity of the protease

\begin{tabular}{ll}
\hline Compound(concentration in mM) & Caseinolytic activity (\%) \\
\hline Control & 100 \\
$\mathrm{MgSO}_{4}(5)$ & 109 \\
$\mathrm{ZnSO}_{4}(5)$ & 77.2 \\
$\mathrm{EDTA}(5)$ & 92.5 \\
$\mathrm{EDTA}(5)+\mathrm{ZnSO}_{4}(5)$ & 82.5 \\
$\mathrm{EDTA}(5)+\mathrm{MgSO}_{4}(5)$ & 102 \\
$\mathrm{EDTA}(5)+\mathrm{CuSO}_{4}(5)$ & 84.2 \\
$\mathrm{NaCl}(100)$ & 100 \\
$\operatorname{NaCl}(200)$ & 100 \\
$\beta-M e r c a p t o e t h a n o l(5)$ & 44.9 \\
Sodium thiosulfate(5) & 78.9 \\
Potassium permanganate & 96.7 \\
\hline
\end{tabular}

A Caseinolytic activity is expressed as the percentage of the control value (with no addition).

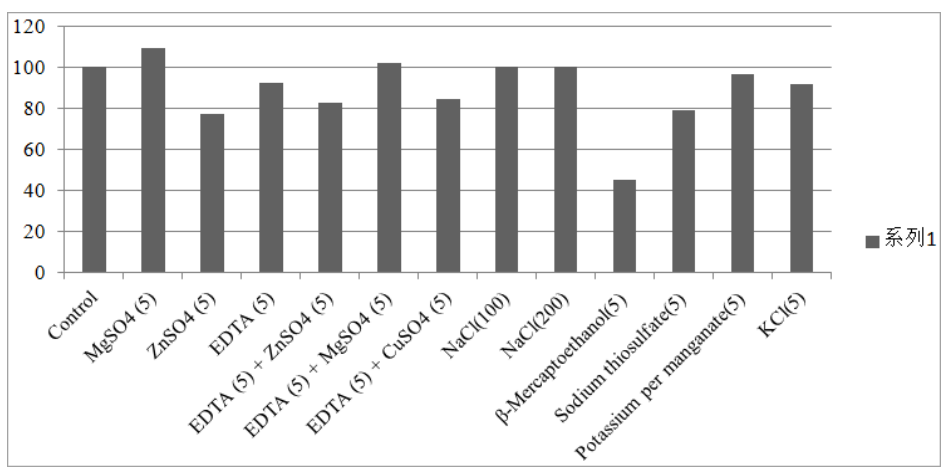

Fig 3. Graphical presentation of effects of salts and other chemicals on the activity of the protease 
The result shows that $5 \mathrm{mM} \mathrm{Mg}^{++}$ion slightly increased the activity of the enzyme while $\mathrm{Zn}^{++}$showed slightly decrease. Other elements $\mathrm{Na}^{+}, \mathrm{K}^{+}$had no effect on the enzyme. EDTA showed no effect on the protease activity which suggested that the enzyme might not be metallo protease. The enzyme activity was significantly reduced by $\beta$ - Merceptoethanol. $\beta$-Mercaptoethanol has been reported to stabilize cystein proteases by protecting the oxidation of sufhydral group in proteins [19]. No effect of EDTA was detected on enzyme activity suggesting that the metal might not be involved in enzyme activity [15].

\subsection{Determination of Bacteria Growth Profile and Protease Activity at $37^{\circ} \mathrm{C}$}

The bacterium was grown in nutrient broth at $37^{\circ} \mathrm{C}$. Samples were taken at different time interval and absorbance was taken at $600 \mathrm{~nm}$ to measure the growth profile. The growth profile of the organism showed optimum growth after about 24 hours and the protease activity was the maximum after 26 hours of incubation. In the initial stage of growth there was basal level of extracellular protease which increased with the increase of time. The result showed that there was differential synthesis of enzyme with growth time.

\subsection{Direct Dehairing Activity of the Enzyme}

The hair removing activity of the culture fitrated was tested on $8^{\prime \prime} \times 8^{\prime \prime}$ leather for different time interval. Culture supernatant containing enzymes had direct effect to remove hair from leather. Hair removing efficiency increase with incubation time and amount of enzyme. So the use of microbial enzymes as an alternate technology to the conventional methods, and highlights the importance of these enzymes in minimizing the pollution loads.

Table 6. Bacterial Growth profile and protease activity at $37^{\circ} \mathrm{C}$.

\begin{tabular}{lll}
\hline Time at hours & Absorbance at 600nm & Absorbance at $440 \mathbf{~ n m}$ \\
\hline 4 & 0.562 & 0.030 \\
6 & 0.756 & 0.052 \\
8 & 0.864 & 0.141 \\
10 & 0.978 & 0.185 \\
12 & 1.132 & 0.212 \\
13 & 1.197 & 0.403 \\
14 & 1.257 & 0.569 \\
15 & 1.357 & 0.578 \\
16 & 1.393 & 0.844 \\
18 & 1.432 & 1.108 \\
20 & 1.604 & 1.497 \\
22 & 1.731 & 1.612 \\
24 & 1.826 & 1.836 \\
26 & 1.75 & 1.924 \\
28 & 1.728 & 1.735 \\
\hline
\end{tabular}
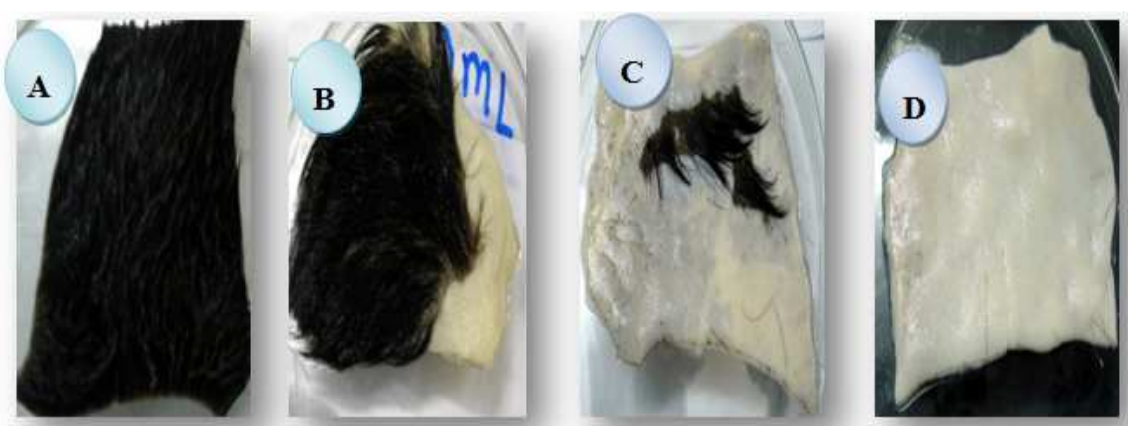

Fig 4. Direct dehairing activity of the enzyme - A (Control), B (10\% Hair removed), C (90\% Hair removed), D (100\% Hair removed)

Table 7. Direct De-Hairing activity of the enzyme with different incubation priod

\begin{tabular}{|c|c|c|c|}
\hline \multirow{2}{*}{$\begin{array}{l}\text { Incubation priod } \\
\text { (hrs) }\end{array}$} & \multirow{2}{*}{$\begin{array}{l}\text { Culture suprenatant } \\
(\mathrm{mL})\end{array}$} & Observation & \multirow{2}{*}{ Control } \\
\hline & & Enzyme effects & \\
\hline \multirow{4}{*}{6} & 10 & No hair removed from the skin. & \multirow{14}{*}{$\begin{array}{l}\text { No } \\
\text { hair } \\
\text { removed }\end{array}$} \\
\hline & 20 & No hair removed but folicles become softerr. & \\
\hline & 30 & $5 \%$ hair were removed by gentlerubbing. & \\
\hline & 40 & More than $5 \%$ hair were removed by gentle rubbing. & \\
\hline \multirow{4}{*}{7} & 10 & $\begin{array}{l}5 \% \text { hair were removed by gentle hand. After few huors incubation with tap water almost } \\
60 \% \text { were removed. }\end{array}$ & \\
\hline & 20 & $30 \%$ hair were removed by gentle rubbing. & \\
\hline & 30 & More than $50 \%$ hair were removed with gentle rubbing. & \\
\hline & 40 & More than $70 \%$ hair were removed with gentle rubbing. & \\
\hline \multirow{3}{*}{8} & 10 & $30 \%$ hair were removed by gentle rubbing. & \\
\hline & 20 & $70 \%$ hair were removed by gentle rubbing. & \\
\hline & 30 & $100 \%$ hair were removed by gentle rubbing. & \\
\hline \multirow{3}{*}{12} & 10 & More than $30 \%$ hair were removed by gentle rubbing. & \\
\hline & 20 & More than $80 \%$ hair were removed by gentle rubbing. & \\
\hline & 30 & $100 \%$ hair were removed by gentle rubbing. & \\
\hline
\end{tabular}




\subsection{Comparison of De-Hairing Ability of Bacillus Subtilis with other Bacteria}

De-hairing ability of the protease produced by our strain and other bacterial protease showed that our bacterial protease is very fast in de-hearing compared to other three.

Table8. Comparison of De-Hairing ability of B. subtilis with other bacteria (1)

\begin{tabular}{lll}
\hline & Time of incubation for de-hairing & Change of color of leather \\
\hline Bacillus sp. & $9 \mathrm{~h}$ & no change \\
Vibrio sp kr2 & $24 \mathrm{~h}$ & no change \\
Flavobacterium sp kr6 & $24 \mathrm{~h}$ & no change \\
Bacillus sp kr10 & $24 \mathrm{~h}$ & no change \\
\hline
\end{tabular}

\section{Discussion}

A bacterium isolated from local soil sample showing de-hearing activity of cattle hides and skins both qualitatively and quantitatively. After various tests it was suggested and the features agreed with the description of Bacillus sp in Bergey's Manual of Systematic Bacteriology [24].

It was also identified as Bacillus sp with $99.9 \%$ identity by API $50 \mathrm{CHB}$ and was also characterized and identified by using a bioinformatics tool PIB (Probabilistic Identification of Bacteria) that suggests the organism was $B$. subtilis $(I D=0.9760)$. Biochemical characteristics, morphological tests indicate that the organisms might be Bacillus. B. pumilis [2], B. licheniformis [8, 12]. Phylogenetic characterization using 16S rRNA gene primer could correctly classify the bacteria species.

Assocasein assay developed by Krege and Lockout is a well accepted method for the assay of wide variety of protease having overlapping specificity. This assay method is simple, easy and quick. A number of protease from different bacteria can be assayed at a time by using this method. Bacillus species have been reported to produce proteases [13, 25, and 27]. Therefore, it may be called a very good method for the large scale screening of bacterial protease $[14,11]$

The characteristics of the culture filtrate suggest that it contain an extracellular enzyme secreted by the bacterium. The enzyme hydrolyses a number of proteins including azocasein which suggest that it is an extracellular protease [4]. The assay condition was set up and the optimum temperature and $\mathrm{pH}$ of the enzyme was determined. The enzyme seems to have an optimum activity temperature of $60^{\circ} \mathrm{C}$ and $\mathrm{pH} 8.5$. This suggests that the enzyme might be an alkaline protease. A number of workers reported the isolation and characterization of alkaline protease from bacillus strain. This result is quite consistent with the work of other works. The enzyme seems to have an optimum temperature of $60^{\circ} \mathrm{C}$. Most proteases possess an optimum activity in the range of $30 \sim 80{ }^{\circ} \mathrm{C}$, for example, protease from $B$. pseudofirmus AL-89 is of $60 \sim 70{ }^{\circ} \mathrm{C}$ [10], Nocardiopsis sp. TOA-1 is of $60{ }^{\circ} \mathrm{C}$ and a few have exceptionally high temperature optimum of $100{ }^{\circ} \mathrm{C}$ (18).

The gram staining showed that the bacteria were Gram-positive rod because the cells had a purple color under the microscope using a $100 \mathrm{X}$ (oil immersion) lens. The cellular arrangements of the bacteria were in chains. The spore staining gave green color that means it forms spore. In growth curve determination showed that the growth of the organism is increased with the increase of incubation period and the growth reached maximum at around 24 hours of incubation and the protease activity was the maximum of the 26 hours culture.

The effect of a number of ions on the activity of the enzyme was observed. $\mathrm{Mg}^{++}$at $5-10 \mathrm{mM}$ level slightly enhances the enzyme activity while $\mathrm{Zn}^{++}$ions slightly decrease the activity of the enzyme. $\beta$ - Mercepto ethanol is an inhibitor of protease. $\beta$-Mercaptoethanol has been reported to stabilize cystein proteases by protecting the oxidation of sufhydral group in proteins [23]. No effect of EDTA was detected on enzyme activity suggesting that the metal might not be involved in enzyme activity [15].

Goat's and cow's skin was qualitatively dehaired by overnight grown bacterial culture. The skin could be dehaired at room temperature within 8-12 hours. This was followed by dehairing with cell free extracts or culture filtrates. The culture filtrate could dehair the skin in specified time. Quantitative estimation has shown that $30 \mathrm{~mL}$ of culture supernatant could dehair $8 \times 8 \mathrm{~cm}$ of leather completely in 8 hours. This shows that the bacterial isolate produce moderate to high amount of enzyme for dehairing. Enzymatic dehairing in tanneries has been envisaged as an alternative to sulfides [16].

\section{Conclusion}

The culture characteristics and biochemical tests of the organism suggest that it is a thermophilic, Gram positive, spore forming and aerobic bacteria. Probabilistic identification of bacteria (PIB) is a bioinformatics tool that identified the bacteria was Bacillus sp. The characterization of protease so far showed that it is an alkaline protease, highly active at temperature near $60^{\circ} \mathrm{C}$. It may contain disulfide bonds and may be halo tolerant. The sequencing of the protein and identification of the gene is the future plan of the research work. As the bacterial protease showed high activity in dehairing of cattle hides and skins, our next target is to introduce it to the tannery industries, so that they can use it instead of hazardous chemicals for better leather quality and most importantly for a better environment. 


\section{Acknowledgements}

We are thankful to all staffs and their kindness and financial support of the Department of Biotechnology and Genetic Engineering, Islamic University, Bangladesh and Vaccine research Laboratory, Gono University, Bangladesh.

\section{References}

[1] Alessandro Riffel, Adriano Brandelli (2003). De-hairing activity of extracellular proteases produced by keratinolytic bacteria. J. of Chem. Technol. \& Biotech. 78 (8), 855-859

[2] Burtt, E. H., \& Ichida, J. M.(1999).Bacteria useful for degrading keratin.US Patent 6214676.

[3] Cantera, C. S., A. R. Angelinetti, G. Altobelli, and G. Gaita (1996). Hairsaving enzyme assisted dehairing. Influence of enzymatic products upon final leather quality. J. Soc. Leather Technol. Chem. 80:83-86.

[4] Cappuccino, J.G. and Sherman, N. (2001). Microbiology: A Laboratory Manual. $6^{\text {th }}$ Edition. Benjamin Cumings.CA.

[5] Cassano, A., E. Drioli, R. Molinari, D. Grimaldiand M. Rossi (2000). Enzymatic membrane reactor for eco-friendly goat skin dehairing. J. Soc. Leat.Technol. Chem. 84:205-211.

[6] Dhar S.C., Sreenivasulu S. (1984). Studies on the use of dehairing enzyme for its suitibilty in the preparation of improved animal feed. Leather Sci., 31: 261-267.

[7] El-Refai, M.H.; Fatah,A.F.A. (2005). Improvement of the newly isolated Bacillus pumilus FH9 Keratinolytic activity. Process Biochem., 40, 2325-2332.

[8] Evans KL, Crowder J, Miller ES (2000). Subtilisins of Bacillus spp. hydrolyze keratin And allow growth on feathers. Can. J. Microbiol. 6:1004-1011.

[9] George, S., V. Raju, M. R. V. Krishnan, T. V. Subramanian, and K. Jayaraman(1995). Production of protease by Bacillus amyloliquefaciens in solid-state fermentation and its application in the dehairing of hides and skins. Process Biochem. 30:457-462.

[10] Gessesse, A., Rajni, H.K., Gashe, B.A. (2003). Novel alkaline proteases from alkaliphilic bacteria grown on chicken feather. Enzyme Microb. Technol., 32 (5):519-524.

[11] Hartree E.E. (1972). This modification makes the assay linear over a largerrange than the original assay. Anal. Biochem. 48:422

[12] Ichida J. M., L. Krizova, C. A. LeFevre, H. M. Keener, D. L. Elwell \& E. H. Burtt (2001). Journal of Microbiology Methods, 47, 199

[13] Kim J.D. (2004). Purification and Characterization of a
Keratinase from a Feather-Degrading Fungus, Aspergillus flavus Strain K-03. Microbiology, No. 35 (4), 219-225.

[14] Lowry, O.H., Rosebrough, N.J., Farr, A.L., and Randall, R.J. (1951) J.Biol.Chem 193: 265

[15] Madern, D. and Zaccai, G(2000).Halophilic adaptation of enzymes. Extremophiles, 4,91-98.

[16] Mitsuiki, S., Sakai, M., Moriyama, Y., Goto, M., Furukawa, K. (2002). Purification and some properties of akeratinolytic enzyme from an alkaliphilic Nocardiopsis sp. TOA-1. Biosci. Biotechnol. Biochem. 66 (1), 164-167.

[17] Mukhopadyay R.P., Chandra A.L. (1993). Protease of keratinolytic Streptomycetes to unhair goat skin. Indian J. Exp. Biol., 31: 557-558.

[18] Nam and Y. R. Pyun(2002). Native-feather degradation by Fervidobacterium islandicum, a newly isolated keratinase-producing thermophilic anaerobe. Arch. microbiol. 178:538-547.

[19] Purushotham, H., S. Malathi, P. V. Raoand K. V. Raghavan (1994). Dehairing enzyme by solid state fermentation. J. Soc. Leather Technol. Chem. 80:52-56.

[20] Puvanakrishnan, R. and Dhar, S. C., (1986). Leather Sci., 33, 177-191

[21] Raju AA, Chandrababu and Rao NM. (1996). Eco-friendly enzymatic dehairing using extracellular proteases from a Bacillus species. J Am Leather Chem. Assoc. 91: 115-119

[22] [Rozs M, Manczinger L, Vágvölgyi C, Kevei F. (2001). Secretion of a trypsin- like thiol protease by a new keratinolytic strain of Bacillus licheniformis. 205: 221-224.

[23] [Rozs M, Manczinger L, Vágvölgyi C, Kevei F. (2001). Secretion of a trypsin- like thiol protease by a new keratinolytic strain of Bacillus licheniformis. 205: 221-224.

[24] Scopes, R.K., 1982. "Protein Purification: Principle and practice," Springer-Verlag, New York, pp 195-196.

[25] Sneath, P.H.A., Mair, N.S., Sharpe, M.E. \& Holt, J.G., (1986). Bergey's Manual of Systematic Bacteriology, Vol. 2 Baltimore: Williams and Wilkins. ISBN 0-683-07893-3

[26] Suntornsuk W and Oda K (2005).Purification and characterization of keratinase from a thermotolerant featherdegrading bacterium. J. Ind. Microbiol. Biotechnol. 21: 1111-1117

[27] THYS and BRANDELLI, A. (2004). Characterization of a protease of a feather-degrading. Microbacterium species. Letters in Applied Microbiology, February, 39 (2) 181-186.

[28] Zerdani I, Faid M, Malki A. (2004). Feather wastes digestion by new isolated strains Bacillus sp. in Morocco. Afr. J. Biotech. 3: 67-70. 